\title{
Pattern of humoral immune response to Plasmodium falciparum blood stages in individuals presenting different clinical expressions of malaria
}

\author{
Fabiana MS Leoratti ${ }^{1}$, Rui R Durlacher ${ }^{1}$, Marcus VG Lacerda ${ }^{2}$, \\ Maria G Alecrim ${ }^{2}$, Antonio W Ferreira ${ }^{1}$, Maria CA Sanchez ${ }^{1}$ and \\ Sandra L Moraes*1
}

Address: ${ }^{1}$ Institute of Tropical Medicine of São Paulo, University of São Paulo, Av. Dr. Enéas de Carvalho Aguiar, 470, 05403-000, São Paulo, Brazil and ${ }^{2}$ Foundation of Tropical Medicine of Manaus, Amazonas, Brazil

Email: Fabiana MS Leoratti - saintgermainna@yahoo.com.br; Rui R Durlacher -rdurlacher@yahoo.com.br;

Marcus VG Lacerda - marcuslacerda@uol.com.br; Maria G Alecrim - malecrim@niltonlins.br; Antonio W Ferreira - clawsmbf@usp.br; Maria CA Sanchez - arroyo@usp.br; Sandra L Moraes* - sands@usp.br

* Corresponding author

Published: 24 September 2008

Malaria Journal 2008, 7:186 doi:10.1/86/1475-2875-7-186

This article is available from: http://www.malariajournal.com/content/7/I//86

(C) 2008 Leoratti et al; licensee BioMed Central Ltd.

This is an Open Access article distributed under the terms of the Creative Commons Attribution License (http://creativecommons.org/licenses/by/2.0), which permits unrestricted use, distribution, and reproduction in any medium, provided the original work is properly cited.
Received: 4 June 2008

Accepted: 24 September 2008

\begin{abstract}
Background: The development of protective immunity against malaria is slow and to be maintained, it requires exposure to multiple antigenic variants of malaria parasites and age-associated maturation of the immune system. Evidence that the protective immunity is associated with different classes and subclasses of antibodies reveals the importance of considering the quality of the response. In this study, we have evaluated the humoral immune response against Plasmodium falciparum blood stages of individuals naturally exposed to malaria who live in endemic areas of Brazil in order to assess the prevalence of different specific isotypes and their association with different malaria clinical expressions.

Methods: Different isotypes against $P$. falciparum blood stages, $\lg G, \lg \mathrm{I}$, $\lg G 2, \lg G 3, \lg G 4, \lg M$, $\lg E$ and $\lg A$, were determined by ELISA. The results were based on the analysis of different clinical expressions of malaria (complicated, uncomplicated and asymptomatic) and factors related to prior malaria exposure such as age and the number of previous clinical malaria attacks. The occurrence of the HI3I polymorphism of the Fc $\gamma$ IIA receptor was also investigated in part of the studied population.

Results: The highest levels of $\operatorname{lgG}$, IgGI, IgG2 and IgG3 antibodies were observed in individuals with asymptomatic and uncomplicated malaria, while highest levels of $\lg \mathrm{G} 4$, $\lg \mathrm{E}$ and $\lg \mathrm{M}$ antibodies were predominant among individuals with complicated malaria. Individuals reporting more than five previous clinical malaria attacks presented a predominance of $\lg G \mathrm{I}, \lg G 2$ and $\lg G 3$ antibodies, while $\lg M$, $\lg A$ and $\lg E$ antibodies predominated among individuals reporting five or less previous clinical malaria attacks. Among individuals with uncomplicated and asymptomatic malaria, there was a predominance of high-avidity IgG, IgG I, IgG2 antibodies and low-avidity IgG3 antibodies. The HI3I polymorphism was found in $44.4 \%$ of the individuals, and the highest lgG2 levels were observed among asymptomatic individuals with this allele, suggesting the protective role of $\lg \mathrm{g} 2$ in this population.

Conclusion: Together, the results suggest a differential regulation in the anti-P. falciparum antibody pattern in different clinical expressions of malaria and showed that even in unstable transmission areas, protective immunity against malaria can be observed, when the appropriated antibodies are produced.
\end{abstract}




\section{Background}

The acquisition of natural immunity to malaria is slow and requires repeated parasite exposure to be maintained [1]. This immunity reduces the risk of both severe and mild malaria but does not suppress parasitaemia. The defense mechanisms require cooperation among antibodies (Ab) and cellular immune responses [2]. There is evidence that (Ab)-dependent mechanisms play an important role in the reduction of parasitaemia and can diminish clinical symptoms in humans, as demonstrated by the passive transfer of hyperimmune immunoglobulin G (IgG) $[3,4]$.

Cooperation between monocytes and $\mathrm{Ab}$ appears to be crucial in acquired protective immunity [5]. The Ab produced in response to infection are of particular importance, since certain isotypes known as cytophilic Ab can cooperate with monocytes via Fc $\gamma$ RI and Fc $\gamma$ RII receptors in opsonization and phagocytosis or participate in both antibody-dependent cellular inhibition (ADCI) as well as antibody-dependent cellular cytotoxicity (ADCC) [6-8]. Protection against the blood stage of Plasmodium falciparum seems to depend on the proportion of specific cytophilic Ab relative to the proportion of non-cytophilic $\mathrm{Ab}$ [9]. The predominance of $\mathrm{IgG}_{1}$ and $\mathrm{IgG}_{3}$ cytophilic $\mathrm{Ab}$ in endemic areas has been associated with either lower parasitaemia [10] or a lower risk of malaria attack [11,12]. Otherwise, noncytophilic $\mathrm{Ab}$, such as $\operatorname{IgG}_{4}$, may inhibit effector mechanisms by competing with cytophilic $\mathrm{Ab}$ and are considered nonprotective $[7,13] . \operatorname{IgG}_{2}$ is noncytophilic, but could be correlated with protection in individuals carrying a specific allelic variant of monocytes Fc $\gamma$ RIIA receptor that can bind $\operatorname{IgG}_{2}[14]$.

IgE levels and IgE anti-plasmodial $\mathrm{Ab}$ are elevated in human and experimental malaria infections, but their role in protection and/or pathogenesis is not well-established in malaria [15-17]. In fact, a negative correlation between the IgE level and placental parasitaemia $[18,19]$ and levels of haemoglobin and platelets [20] has been found. The IgE level was higher in cerebral $P$. falciparum malaria than in uncomplicated malaria $[16,21]$, while among patients with severe malaria, the increase in IgE levels was related to the deepness of the coma [20]. Recent data showed higher IgE functional activity in asymptomatic and uncomplicated malaria patients than in severe or cerebral malaria groups [22].

Contradictory results have been also found in relation to IgM Ab. Even though there are indirect epidemiological data suggesting that IgM Ab does not participate in protection $[23,24]$, some evidence suggests a protective role in cases such as: (a) mice with an X-linked recessive B-cell deficiency do not produce IgM and are susceptible to Plasmodium yoelii [24]; (b) the addition of monoclonal IgM
$\mathrm{Ab}$ to a malaria vaccine, raising its protective properties [25]; (c) the IgM level, which correlated with a decrease of the parasitaemia in individuals living in an area of hyperendemic malaria [26]. In terms of IgA Ab, no specific function in malaria has been ascribed to these antibodies to date.

The gradual development of natural immunity to malaria has been observed in areas where malaria transmission is high and stable. The great majority of the studies on the prevalence of different immunoglobulin isotypes and their role in malaria infection has been conducted in such areas, but little is known about areas with unstable malaria, such as the Amazon Basin of Brazil. The main objective of this work was to compare the humoral immune response in three groups of Plasmodium-infected subjects living in malaria endemic areas of Brazil: (a) subjects with non-cerebral complicated malaria, (b) subjects with uncomplicated malaria, and (c) asymptomatic subjects - investigating the distribution of $P$. falciparum blood stages-specific isotypic Ab IgG, IgG1, IgG2, IgG3, IgG4 $\operatorname{IgM}, \operatorname{IgE}$ and IgA. The avidity of IgG subclasses, a parameter of humoral immune response quality that has received little attention in studies on malaria, was also evaluated in this study.

\section{Materials and methods \\ Study area, subjects and serum samples}

Venous blood samples were collected from 233 residents from two cities, Peixoto de Azevedo and Manaus, in the Amazon Basin of Brazil. Peixoto de Azevedo is in the state of Mato Grosso (PA/MT) and Manaus is the capital of the state of Amazonas (MA/AM). The equatorial and humid climate of both cities is characterized by a rainy season from November to April and a dry season from May to October. Malaria transmission is unstable, with an increase at the end of the rainy season. Informed consent was obtained individually from all participants before the blood sample was taken. This study was approved by the Committee of Ethics of the Faculty of Medicine of the University of São Paulo, of the Institute of Tropical Medicine of São Paulo (IMT/SP) and of the Foundation of Tropical Medicine of Amazonas (FMT/AM). A questionnaire containing vital statistics and reports of the number of previous malaria attacks was available from all individuals.

At the time of blood collection, thick blood films and/or QBC $^{\circledast}$ (Quantitative Buffy Coat) were prepared according to standard protocols for all subjects. Based on the clinical expression of malaria, three groups were defined: (a) 70 subjects presenting non-cerebral complicated malaria (52 P. falciparum and 18 Plasmodium vivax) (CM group); (b) 148 subjects presenting uncomplicated malaria (92 P. falciparum, 32 P. vivax, 23 P. falciparum and $P$. vivax, and 1 Plasmodium malariae) (UM group), and (c) 15 subjects 
with Plasmodium infection, but without malaria symptoms (9 P. falciparum, $1 P$. vivax, $4 P$. falciparum and $P$. vivax, and $1 P$. malariae) (AS group). Non-cerebral complicated malaria was defined as either severe anaemia and/or high parasitaemia, hypoglycaemia $<40 \mathrm{mg} / \mathrm{dL}$, serum creatinine level $>1,5 \mathrm{mg} / \mathrm{dL}$. Uncomplicated malaria was characterized by a positive blood smear and fever without other causes of infections and no manifestations of severe malaria as described above. Ninety serum samples from malaria-naïve blood donors were used as negative control in the assays. Table 1 shows some characteristics of the population.

\section{Enzyme-linked immunosorbent assay (ELISA) for IgG subclasses and IgE $A b$}

IgG subclasses and IgE Ab were detected with ELISA using a Zwittergent-extracted $P$. falciparum blood stages antigen as described above [27]. Flat-bottom plastic microplates (Polysorb, NUNC) were coated with a $P$. falciparum antigen diluted to $5 \mu \mathrm{g} / \mathrm{mL}$ in phosphate buffered saline (PBS) $(50 \mu \mathrm{L} /$ well $)$ for $2 \mathrm{~h}$ at $37^{\circ} \mathrm{C}$ and subsequently for $18 \mathrm{~h}$ at $4{ }^{\circ} \mathrm{C}$ in a moist chamber. Plates were saturated with $5 \%$ skim milk in PBS-Tw20 $(200 \mu \mathrm{L} /$ well $)$ for $1 \mathrm{~h}$ at $37^{\circ} \mathrm{C}$. Serum dilutions in $1 \%$ skim milk in PBS-Tw20 (serum diluent) $(50 \mu \mathrm{L} /$ well $)$ were incubated for $40 \mathrm{~min}$ at $37^{\circ} \mathrm{C}$ in duplicate wells, 1:50 for IgG1, IgG2 and IgG3, 1:5 for IgG4. For IgE detection, IgG Abs were first depleted by treating them with a 1:20 serum dilution with a sheep anti-human IgG (Rf-absorbent, Dade Behring) (1:1). The biotinylated sheep anti-human IgE antibody (Sigma Chem. Co.) was diluted to 1:500 in serum diluent $(50 \mu \mathrm{L} /$ well) and biotinylated mouse monoclonal Ab specific to each IgG isotype were used at the following dilutions in serum diluent $(50 \mu \mathrm{L} /$ well): anti-IgG1 (clone 8c/6-39; Sigma Chem. Co.), 1:1,000; anti-IgG2 (clone HP 6014; Sigma Chem. Co.), 1:500; anti-IgG3 (clone HP 6050; Sigma Chem. Co.), 1:500; anti-IgG4 (clone HP 6025; Sigma Chem. Co.), 1:500. The peroxidase-labeled streptavidin was diluted to $1: 1,000(50 \mu \mathrm{L} /$ well $)$ in serum diluent and incubated for $40 \mathrm{~min}$ at $37^{\circ} \mathrm{C}$. The enzymatic reaction was developed with hydrogen peroxide and tetramethylbenzidin (Sigma Chem. Co.) diluted in citrate-phosphate buffer $\left(\mathrm{H}_{2} \mathrm{O}_{2}-\mathrm{TMB}\right)(50 \mu \mathrm{L} /$ well $)$ for 30 minutes at $37^{\circ} \mathrm{C}$, and the reaction was stopped with $25 \mu \mathrm{L} /$ well of $2 \mathrm{~N}$ $\mathrm{H}_{2} \mathrm{SO}_{4}$. Spectrophotometric reading at $450 \mathrm{~nm}$ was per- formed on a Titertek Multiskan (MKII)-MCC/340 spectrophotometer.

The results were expressed as a reactivity index (RI) or concentration. The reactivity index (RI) was calculated as the ratio of the serum sample optical density to the cut-off optical density. Serum samples with an RI equal to or greater than 1.0 were considered positive. The cut-off was defined as the mean plus 2 SD of the optical density values obtained with 90 negative control sera. Standard curves were drawn by testing in each microplate six serial dilutions $(5120,1280,320,80,20$ and $5 \mathrm{ng} / \mathrm{mL})$ of myeloma protein of any the four IgG subclasses (Sigma Chem. Co.) or IgE myeloma. Coating was done as described above with $50 \mu \mathrm{L} /$ well of a mixture (1:1) of one $\kappa$ and one $\lambda$ myeloma protein of each isotype. Concentrations of antigen-bound Ig isotypes were calculated from standard curves using a four-parameter log-logit function, with the aid of the ELISA programme developed by Plikyatis et al [28]. Competition experiments with IgG1, IgG2, IgG3 and IgG4 purified myeloma (Sigma Chem. Co.) were performed to check the specificity of anti-human IgG subclasses and no cross-reaction was observed.

The avidity of anti-P. falciparum IgG and IgG subclasses was assessed with an urea-elution based ELISA. Microplates were coated and saturated as described above. After serum samples were incubated, $8 \mathrm{M}$ urea in PBS was added $(100 \mu \mathrm{L} /$ well) for $5 \mathrm{~min}$ to one of the duplicates, while PBS-Tw20 was added to the other duplicate. After washing, the assay was completed as described above. The avidity index (IA) was calculated as the ratio of the ureatreated serum sample optical density to the non-treated serum sample optical density, and multiplied by 100 . All values higher than $50 \%$ were ranked as high avidity and values equal or lower than $50 \%$ were considered low avidity.

\section{ELISA for IgG, IgM and IgA Ab}

Slight differences were noted among anti-P. falciparum IgG, IgM and IgA Ab when analysed as described above. Serum dilutions in serum diluent $(50 \mu \mathrm{L} /$ well) were incubated for $40 \mathrm{~min}$ at $37^{\circ} \mathrm{C}$ in duplicate, 1:100 for IgG and IgM, and 1:25 for IgA. The peroxidase-labeled sheep antihuman IgG, IgM and IgA were diluted to $1: 10,000$,

Table I: Characteristics of the studied population.

\begin{tabular}{|c|c|c|c|c|}
\hline \multirow[t]{2}{*}{ Characteristics } & \multicolumn{3}{|c|}{ Clinical expressions of malaria } & \multirow{2}{*}{$\begin{array}{c}\text { Total } \\
\mathrm{n}=233\end{array}$} \\
\hline & $C M(n=70)$ & UM $(n=148)$ & AS $(n=15)$ & \\
\hline median age in years $(25 \%-75 \%)$ & $25.8(17.0-40.0)$ & $28.0(22.0-37.0)$ & $30.0(25.8-39.5)$ & 30.2 \\
\hline Sex (male/female \%) & $48.4 / 51.6$ & $82.4 / 17.6$ & $86.7 / 13.3$ & \\
\hline mean number of previous malaria attacks & $3.7 \pm 6.5$ & $11.9 \pm 8.9$ & $14.8 \pm 8.3$ & 10.2 \\
\hline
\end{tabular}

$\mathrm{CM}=$ complicated malaria, $\mathrm{UM}=$ uncomplicated malaria, $\mathrm{AS}=$ asymptomatic infection 
$1: 20,000$ and $1: 2,000$, respectively, in serum diluent (50 $\mu \mathrm{L} /$ well) and incubated for $40 \mathrm{~min}$ at $37^{\circ} \mathrm{C}$. The enzymatic reaction was developed with $\mathrm{H}_{2} \mathrm{O}_{2}-\mathrm{TMB}(50 \mu \mathrm{L} /$ well) for 30 minutes at $37^{\circ} \mathrm{C}$, and the reaction was stopped with $25 \mu \mathrm{L} /$ well of $2 \mathrm{~N} \mathrm{H}_{2} \mathrm{SO}_{4}$. A spectrophotometric reading at $450 \mathrm{~nm}$ was performed on a Titertek Multiskan (MKII)-MCC/340 spectrophotometer.

\section{Total human IgE and IgA measurement}

The concentrations of total human IgE and IgA were determined in 66 serum samples from malaria endemic areas using commercial nephelometry kits (Dade-Behring, Germany).

\section{Determination of Fc/RIIA HIR I 3 I polymorphism}

FcyRIIA H/R131 polymorphism was determined in 126 DNA samples from the subjects by using an allele specific restriction enzyme digestion method [29]. DNA extraction was performed as described by Snounou et al [30] and modified by Ferreira et al [31]. First, the Fc $\gamma$ RIIA-H/R gene was amplified by PCR and the resulting product was digested by the Bsh1236I (FnuDII) enzyme. The H131 allele contains a Bst $\mathrm{UI}$ site in the $3^{\prime}$ region and the R131 allele contains two Bst $\mathrm{UI}$ sites in the $3^{\prime}$ and $5^{\prime}$ regions. After BstUI digestion, the H/H131 genotype produces a 343 fragment, the R/R131 genotype produces a 322 fragment and the H/R131 genotype produces one of each fragment.

\section{Statistical analysis}

Analysis was carried out using SigmaStat software (Jandel Scientific Corporation, CA). Antibody frequencies among the three malaria groups were assessed by a $\chi^{2}$-test. Antibody levels in the three malaria groups were compared using the non-parametric Kruskal-Wallis (KW) test and the Mann-Whitney (MW) test when two groups were compared. Correlations were assessed by Spearman rank test (Sp), using real or logarithmically transformed values. $P$ values $\leq 0.05$ were considered significant.

\section{Results}

Pattern of isotype response against $P$. falciparum blood stages considering different clinical expressions of malaria IgG, IgG1, IgG2, IgG3, IgG4, IgM, IgA and IgE isotypes levels were tested in $P$. falciparum blood-stage antigens of 233 Plasmodium-infected subjects presenting different clinical expressions of malaria: complicated malaria (CM), uncomplicated malaria (UM) and asymptomatic malaria (AS). The results are presented on Table 2. Index of avidity of IgG, IgG1, IgG2, IgG3 and IgG4 are also shown.

Levels of anti-P. falciparum IgG1, IgG2 and IgG3 Ab were higher in the UM and AS groups than in the CM group (KW, $P<0.0001)$. In contrast, levels of IgG4 were higher in the $\mathrm{CM}$ group than in the UM and AS groups $(P=$ 0.002). Also, IgE levels were higher in CM but without significant differences (KW, $P=0.07$ ). Levels of IgG, IgM and IgA Ab did not differ among the groups (KW, $P>0.05$ ). Higher avidity indexes were observed for IgG, IgG1 and IgG2 antibodies in the UM and AS groups compared to the CM group (KW, $P=0.036 ; P<0.0001 ; P=0.014$, respectively) (Table 2 ).

Table 2: Results of the levels of different antibodies isotypes and their avidity against $P$. falciparum blood stages determined by ELISA in serum from 233 individuals infected with Plasmodium and classified according to the different clinical expressions of malaria: complicated malaria (CM), uncomplicated malaria (UM) and asymptomatic malaria (AS).

\begin{tabular}{|c|c|c|c|c|}
\hline & \multicolumn{3}{|c|}{ Levels of antibodies against $P$. falciparum blood stages } & \multirow{2}{*}{$\begin{array}{c}\text { Statistical } \\
P\end{array}$} \\
\hline & CM & UM & AS & \\
\hline$|g G| *$ & $2.28(0.80-10.37)$ & $18.40(7.23-44.8)$ & $38.4(3.95-71.8)$ & $<0.0001$ \\
\hline $\mathrm{Al}-\lg \mathrm{GI}+$ & $35.1(24.7-64.7)$ & $66.4(44.4-86.7)$ & $71.9(62.2-84.6)$ & $<0.0001$ \\
\hline $\lg G 2 *$ & $1.33(0.67-3.00)$ & $3.92(2.26-17.1)$ & $9.81(2.25-89.8)$ & $<0.0001$ \\
\hline $\mathrm{Al}-\lg \mathrm{G} 2+$ & $20.4(16.8-68.6)$ & $58.0(37.5-76.6)$ & $75.3(62.0-92.6)$ & 0.014 \\
\hline $\lg G 3 *$ & $0.43(0.19-0.91)$ & $1.53(0.72-3.74)$ & $2.4 \mathrm{I}(0.53-9.47)$ & $<0.0001$ \\
\hline $\mathrm{Al}-\lg \mathrm{g} 3+$ & $43.5(22.0-53.6)$ & $42.9(27.1-66.5)$ & $37.1(29.4-53.3)$ & 0.813 \\
\hline $\lg 4^{*}$ & $0.06(0.00-0.14)$ & $0.01(0.00-0.04)$ & $0.01(0.00-0.03)$ & 0.002 \\
\hline $\mathrm{Al}-\lg \mathrm{g} 4+$ & $40.0(2.8-77.8)$ & $48.9(36.0-59.1)$ & - & $0.47 I$ \\
\hline $\operatorname{lgG\# }$ & $2.47(0.73-5.44)$ & $2.92(1.36-4.39)$ & 4.7। (1.59-6.58) & 0.190 \\
\hline Al-lgG+ & $48.4(34.7-69.7)$ & $63.3(46.8-73.2)$ & $63.4(58.2-69.8)$ & 0.036 \\
\hline $\lg E^{*}$ & $0.07(0.03-0.16)$ & $0.03(0.00-0.11)$ & $0.03(0.01-0.21)$ & 0.07 \\
\hline IgM\# & $1.08(0.65-2.08)$ & $0.86(0.59-1.50)$ & $1.04(0.58-2.00)$ & 0.106 \\
\hline IgA\# & $0.93(0.56-2.09)$ & $0.87(0.60-1.88)$ & - & 0.661 \\
\hline
\end{tabular}

* Levels expressed as concentration median $(\mu \mathrm{g} / \mathrm{mL})$

\# Levels expressed as the index of reactivity (IR) calculated as [sample optical density (OD)/cut-off OD]

$+\mathrm{Al}=$ avidity index mean, calculated as (urea-treated sample OD/PBS sample OD)* 100

$P$ value for Kruskal Wallis non-parametric test 
The prevalence of IgG1, IgG2 and IgG3 Ab was significantly higher in the UM and AS groups than in the CM group $\left(\chi^{2}=42.5 \% ; P<0.0001 ; \chi^{2}=12.7 \% ; P=0.002 ; \chi^{2}\right.$ $=10.1 \% ; P=0.006$, respectively) (Table 3 ). The prevalence of IgG4, IgE, IgG, IgM and IgA Ab did not differ significantly among the three groups $(P>0.05)$. High-avidity IgG, IgG1, IgG2 and IgG4 Ab predominated in the UM and AS groups, while low-avidity Ab predominated in the CM group, although a significant difference was only noted for IgG1 Ab $\left(\chi^{2}=16.4 ; P=0.0003\right)$. Low-avidity IgG3 Ab predominated in the three groups, but with no significant differences $(P>0.05)$ (Table 3$)$.

With regards to the Plasmodium species, there was a significant difference in IgG1 Ab frequency when $P$. falciparum (78.4\%) was compared with $P$. vivax $(62.7 \%)$ infected patients $\left(\chi^{2}=4.16 ; P=0.04\right)$; and when $P$. vivax $(62.7 \%)$ was compared with $P$. falciparum and $P$. vivax $(92.6 \%)$ infected patients $\left(\chi^{2}=6.55 ; P=0.01\right)$. On the other hand, no significant difference was observed for all other $A b$ classes and subclasses studied $(P>0.05)$.

Different immunoglobulin isotypes can react with the same epitopes but can influence the course of an infection differently. In view of this fact, some of the interactions of different isotypes against $P$. falciparum were compared in the groups of subjects presenting different clinical expressions of malaria. Interactions of IgG1, IgG2 and IgG3 were higher among the UM and AS groups, while interactions of IgG4 and IgE were higher in the CM group. Higher IgG2/IgG4 and IgG/IgM ratios were observed in the UM and AS groups (Table 4).

\section{Association with variables indicative of prior malaria exposure}

The influence of age and the number of previous clinical malaria attacks on the levels of the isotypes specific for $P$. falciparum blood-stage antigens was evaluated. Age was positively correlated with $\operatorname{IgG}(\mathrm{Sp}, \mathrm{r}=0.13 ; P=0.033)$, IgG1 (Sp, $\mathrm{r}=0.17 ; P=0.008)$ and IgG2 $\mathrm{Ab}(\mathrm{Sp}, \mathrm{r}=0,16$; $P=0.008)$. The number of previous clinical malaria attacks was positively correlated with IgG, IgG1 (Sp, r = $0.51 ; P=0.00)$, IgG2 (Sp, $\mathrm{r}=0.43 ; P=0.00)$ and IgG3 (Sp, $\mathrm{r}=0.33 ; P=0.00)$, and negatively correlated with IgG4 $(\mathrm{Sp}, \mathrm{r}=-0.23 ; P=0.001)$. Levels of IgG1, IgG2, IgG3 and IgG were significantly higher in subjects reporting more than five previous clinical malaria attacks than among those reporting one to five previous clinical malaria attacks or those undergoing their first malaria episode (KW, $P<0.0001$ ). Conversely, the levels of IgG4 and IgE were significantly higher in subjects undergoing their first malaria episode (KW, $P=0.0004)$. No significant difference was observed in the levels of $\operatorname{IgM}$ and $\operatorname{IgA} \mathrm{Ab}(P>$ $0.05)$.

The mean avidity indexes (mAI) of the IgG1 Ab increased significantly with the number of previous clinical malaria attacks: above five previous clinical malaria attacks (mAI $=71.7 \%$ ), one to five previous clinical malaria attack (mAI $=52.2 \%)$ and the first malaria episode $(\mathrm{mAI}=22.9 \%)$ (KW, $P<0.0001$ ). The AI of IgG, IgG2, IgG3 and IgG4 Ab were not statistically different $(\mathrm{KW}, P>0.05)$.

\section{Determination of total IgE and IgA}

Total IgE and IgA levels were investigated in 66 serum samples of the Plasmodium-infected subjects using a nephelometry assay. The median of the total IgE levels was $1,095 \mathrm{UI} / \mathrm{mL}$, which is higher than normal human levels (100 UI/mL); only four subjects had normal total IgE levels. Of the 62 serum samples with high total IgE levels, 40 (64.5\%) had anti-P. falciparum IgE Ab and 22 (35.5\%) did not $(P=0.002)$. The median of the total IgA levels was $2.00 \mathrm{~g} / \mathrm{L}$, while normal levels are between 0.7 and $2.0 \mathrm{~g} / \mathrm{L}$. Three serum samples showed that total IgA levels were

Table 3: Frequency of antibodies against $P$. falciparum blood stages determined with ELISA in serum from 233 individuals infected with Plasmodium and classified according to the different clinical expressions of malaria: complicated malaria (CM), uncomplicated malaria (UM) and asymptomatic malaria (AS).

\begin{tabular}{|c|c|c|c|c|c|c|}
\hline \multirow{3}{*}{ Isotype } & \multicolumn{6}{|c|}{ Frequency of individuals (\%) } \\
\hline & \multicolumn{2}{|r|}{ CM } & \multicolumn{2}{|r|}{ UM } & \multicolumn{2}{|r|}{ AS } \\
\hline & total & high/low avidity & total & high/low avidity & total & high/low avidity \\
\hline $\lg G \mid$ & 50.0 & $58.8 / 41.2$ & 89.9 & $86.4 / 13.6$ & 73.3 & $100.0 / 0$ \\
\hline $\lg G 2$ & 24.3 & $47.1 / 52.9$ & 47.3 & $85.5 / 14.5$ & 60.0 & $100.0 / 0$ \\
\hline $\lg G 3$ & 41.4 & $65.5 / 34.5$ & 64.2 & $73.1 / / 26.9$ & 60.0 & $66.7 / 33.3$ \\
\hline $\lg G 4$ & 18.0 & $55.6 / 44.4$ & 16.5 & $77.3 / 22.7$ & 6.7 & $100.0 / 0$ \\
\hline $\lg G$ & 71.4 & $81.4 / 18.6$ & 79.1 & $93.8 / 6.2$ & 73.3 & $100.0 / 0$ \\
\hline $\lg \mathrm{E}$ & 39.1 & - & 37.6 & - & 35.7 & - \\
\hline $\lg M$ & 58.6 & - & 39.9 & - & 53.3 & - \\
\hline $\lg A$ & 46.2 & - & 40.0 & - & 60.0 & - \\
\hline
\end{tabular}


Table 4: Comparison of the interactions of isotypes against $P$. falciparum blood stages levels of 233 Plasmodium-infected subjects presenting different clinical expression of malaria.

\begin{tabular}{|c|c|c|c|c|}
\hline \multirow[b]{2}{*}{ Interaction } & \multicolumn{3}{|c|}{ Clinical expression of malaria } & \multirow[b]{2}{*}{$(P)^{*}$} \\
\hline & Complicated & Uncomplicated & Asymptomatic & \\
\hline $\lg G \mid+\lg G 3 / \lg G 2+\lg G 4$ & 2,16 & 3,35 & 1,70 & 0,061 \\
\hline $\lg G \mid+\lg G 2+\lg G 3 / \lg G 4$ & 0,36 & 9,12 & 32,1 & $<0,00$ I \\
\hline $\lg G \mid+\lg G 3 / 2$ & $\mathrm{I}, 45$ & 10,94 & 23,94 & $<0,0001$ \\
\hline $\lg \mathrm{E}+\lg \mathrm{G} 4$ & 0,16 & 0,06 & 0,06 & 0,0100 \\
\hline $\operatorname{lgG} 2 / \operatorname{lgG} 4$ & 12,2 & 154,1 & 482,7 & $<0,0001$ \\
\hline $\operatorname{lgG} 3 / \operatorname{lgG} 4$ & 4,29 & 39,79 & 82,83 & $<0,0001$ \\
\hline $\lg E+\lg G 4 / \lg G 2$ & 0,106 & 0,008 & 0,01 & $<0,0001$ \\
\hline $\lg M / \lg G$ & 0,565 & 0,39 & 0,36 & 0,032 \\
\hline $\lg G / \lg M$ & I,77 & 2,56 & 2,81 & 0,031 \\
\hline $\lg G \mid+\lg G 2+\lg G 3 / \lg M+\lg E+\lg G 4$ & 5,32 & 13,87 & 18,87 & $<0,0001$ \\
\hline
\end{tabular}

*P values were determined by the non-parametric Kruskal Wallis test.

higher than normal, while four serum samples were below normal levels.

\section{Determination of Fc/RIIA HIRI3I polymorphism}

Since the occurrence of FcyRIIA H/R131 polymorphism grants IgG2 Ab a cytophilic function and results show higher IgG2 levels in uncomplicated and asymptomatic malaria than in complicated malaria, the distribution of Fc $\gamma$ RIIA H/R131 in the population was analysed. The FcyRIIA H/R131 genotype was examined using genomic DNA from 126 Plasmodium-infected subjects. Overall, the $\mathrm{H} 131$ allele was found in $44.4 \%$ of the subjects; $15.1 \%$ were $\mathrm{H} / \mathrm{H}, 58.7 \%$ were $\mathrm{H} / \mathrm{R}$ and $26.2 \%$ were $\mathrm{R} / \mathrm{R}$. IgG2 Ab levels were higher in the asymptomatic subjects with the $\mathrm{H} 131$ allele $(78.6 \mathrm{mg} / \mathrm{mL})$ than in those without it $(38.1$ $\mathrm{mg} / \mathrm{mL}$ ), but this difference was not significant. A significant difference was observed in IgG2 levels when asymptomatic subjects with the $\mathrm{H} 131$ allele were compared to symptomatic subjects without the H131 allele $(4.5 \mathrm{mg} /$ $\mathrm{mL})(\mathrm{MW}, P=0.02)$ (Table 5).

\section{Discussion}

In this study it was investigated how IgG and its four subclasses, IgM, IgE and IgA isotypes, work against $P$. falciparum blood stages of individuals naturally exposed to malaria living in different regions of Brazil. The results of the different classes of immunoglobulins were analysed in relation to the different clinical expressions of malaria: complicated (CM), uncomplicated (UM) and asymptomatic (AS) malaria. Factors related to prior malaria exposure such as age and the number of previous clinical malaria attacks were also analysed.

All the subjects were infected with $P$. falciparum and/or $P$. vivax. It is likely that, due to the fact that a great number of these subjects had suffered multiple malaria episodes in the past and as a result of the cross-recognition of antigens, the frequency of antibodies did not differ significantly among the different infections; in any case, all subjects were analysed.

The IgG, IgG1, IgG2 and IgG3 antibody levels and their respective frequencies of positivity were higher in the UM and AS groups than in the CM group. The isotype levels were positively correlated with the number of past malaria attacks and the IgG, IgG1 and IgG2 antibody levels were positively correlated to age. These results are in line with those of other authors who demonstrated that cytophilic antibodies IgG1 and IgG3 were related to uncomplicated malaria. More specifically, several studies showed that

Table 5: IgG2 levels against $P$. falciparum blood stage extract detected with ELISA and the Fc $\gamma$ RIIA HI3I divided into two groups (individuals with or without malaria symptoms) genotype.

\begin{tabular}{|c|c|c|c|c|}
\hline \multirow[t]{2}{*}{ Individuals } & \multirow{2}{*}{$\begin{array}{c}\text { Allele } \\
\text { FcyRIIA HI3I }\end{array}$} & \multicolumn{3}{|c|}{ IgG2 antibodies } \\
\hline & & [] Md & $\mathrm{N}$ pos & $\%$ pos \\
\hline Symptomatic & $R / R(n=29)$ & $4.5(2.5-12.9)$ & 14 & 48.3 \\
\hline$(n=113)$ & $\mathrm{H} / \mathrm{H}$ or $\mathrm{H} / \mathrm{R}(\mathrm{n}=84)$ & $4.4(2.6-18.5)$ & 43 & 51.2 \\
\hline asymptomatic & $R / R(n=4)$ & $5.6(1.5-23.6)$ & 2 & 50.0 \\
\hline$(n=13)$ & $H / H$ or $H / R(n=9)$ & $78.6(4.9-94.2)$ & 7 & 77.8 \\
\hline
\end{tabular}

Md = median of concentration $(\mu \mathrm{g} / \mathrm{mL})$ 
specific IgG1 and IgG3 antibodies could protect against malaria, while lgG4 antibodies probably do not protect against the disease $[5,11,12,32-36]$. A recent study in Sudan also found lower prevalence of IgG antibodies against three $P$. falciparum merozoite surface protein (MSP) MSP antigens, MSP1-19, MSP2A, and MSP2B in individuals with severe malaria than in uncomplicated [37]. A recent cohort study of children in Burkina Faso has investigated different isotypes against four vaccine candidates antigens, apical membrane antigen 1 (AMA1), MSP1-19, MSP3, and glutamate-rich protein (GLURP). They observed association among IgG, IgG3 and IgG4 against GLURP and a borderline association of IgG to MSP3 with reduced risk of malaria [38].

There have been reports of asymptomatic malaria in these Brazilian regions, suggesting that a certain degree of natural immunity can develop $[39,40]$. Considering that the development of immunity depends on the degree of previous exposure to the disease, the positive correlation with factors related to prior malaria exposure suggest that these isotypes could play a role in protection against the disease; this idea is supported by the varying frequencies detected among the different clinical expressions of the illness.

In spite of the fact that the IgG2 antibodies did not participate in the mechanisms that caused opsonization, phagocytosis and ADCI as they do not bind to the Fc $\gamma$ R receptors (principally, Fc $\gamma$ RIIA), the results showed a predominance of IgG2 antibodies among individuals from the UM group. For this, the R131H polymorphism in the Fc $\gamma$ RIIA receptor gene was investigated. Fc $\gamma$ RIIa is a lowaffinity IgG receptor with an important role in neutralizing events of malaria parasites mediated by monocytes [41]. Its ability of binding immunoglobulin subtypes is influenced by a polymorphism within the gene. An amino acid change at position 131 within the Fc $\gamma$ RIIa molecule, arginine (R131) or histidine (H131) is critical for the binding of human IgG2 that binds efficiently to FcyIIaH131 but not to FcyRIIa-R131, although both Fc $\gamma$ RIIa allotypes interact with IgG1 and IgG3 [13]. Previous studies have indicated that Fc $\gamma$ RIIa polymorphism has an impact on the susceptibility/resistance for malaria, although their results have been contradictory. In some studies, the H/H131 genotype was significantly associated with susceptibility to severe malarial disease $[42,43]$ while in other studies the $\mathrm{H} / \mathrm{H} 131$ genotype was associated with mild malaria [44] or the H131 alleles were mildly protective against high-density parasitaemia [45]. In relation to FcyRIIa-R/R131 genotype, it has been associated with protection against high levels of $P$. falciparum parasitaemia [45] and against malarial disease $[43,46]$. In contrast, it was also associated with the development of severe malaria [44]. This discrepancy likely reflects differences in study design or in malaria exposure rates, as well as genetic differences between the populations. Fc $\gamma$ RIIa polymorphism plays an important role in other infections. Fc $\gamma$ RIIa H/H 131 has been associated to protection from encapsulated bacterial infections, in which IgG2 is critical in host defense [47]. The R/R131 genotype has been found to be a risk factor for recurrent bacterial respiratory infections $[48,49]$.

In the present study, the $\mathrm{H} 131$ allele was found in $44.4 \%$ of the subjects; $15.1 \%$ were $\mathrm{H} / \mathrm{H}, 58.7 \%$ were $\mathrm{H} / \mathrm{R}$ and $26.2 \%$ were R/R. The frequency of the $\mathrm{H} 131$ allele was very similar to that observed in a population of Burkina Faso (43\%) [14], when high levels of IgG2 specific for $P$. falciparum antigens were also associated to protection against malaria. Here, the levels of IgG2 Ab were higher in the asymptomatic subjects with the FcyRIIA H/R131 allele $(78.6 \mathrm{mg} / \mathrm{mL})$ than in those without this allele $(38.1 \mathrm{mg} /$ $\mathrm{mL})$, but this difference was not significant. However, a significant difference was found in the levels of IgG2 of asymptomatic individuals with the Fc $\gamma$ RIIA H/R131 allele and the symptomatic individuals without allele H131 $(4.5 \mathrm{mg} / \mathrm{mL})(\mathrm{MW}, P=0.02)$. The high levels of IgG2 that were found in AS individuals carrying the H131 polymorphism could suggest that IgG2 plays a role as a cytophilic antibody among this population.

The IgG4 levels showed a negative correlation with the number of previous malaria episodes. In addition, the frequency of positivity and the IgG4 levels were higher among subjects from the $\mathrm{CM}$ group. The absence of malaria protection in IgG4 antibodies has been observed by other authors [9,14]. IgG4 inhibits the action of cytophilic antibodies lgG1 and lgG3 in vitro; these antibodies are responsible for mediating the opsonization of infected erythrocytes [5]. Aucan et al observed that the positive correlation of IgG4 with the risk of infection was stronger when IgG2 levels were low, suggesting that IgG4 could be neutralizing the cellular cytotoxicity mediated by monocytes or other effector cells that depend on IgG2. Therefore, IgG4 could block the protection provided by IgG2 [14].

Another essential aspect of the humoral immune response is the functional affinity or avidity of the antibodies; this is the measurement of the force between the antigen and the antibody and it can reflect the quality of the antibodies involved in protection or in different phases of the illness. When studying the avidity of anti-P. falciparum blood stages antibodies among populations from the endemic area with stable transmission in Africa and unstable transmission in the Brazilian Amazon Basin, Ferreira et al noted a predominance of high avidity antibodies, particularly IgG1, in the clinically immune African subjects [50]. Among patients from the Brazilian Amazon 
low avidity antibodies were found during the acute phase of the disease; these were probably the result of the polyclonal activation of B cells. Two months following chemotherapy, the proportion of high avidity IgG antibodies had increased significantly, though the concentration of cytophilic antibodies had decreased. These authors postulated that high-quality anti-P. falciparum antibodies could be initially produced during the intra-erythrocytic growth of the parasite, and that these antibodies react when parasitaemias are still low, with higher effectiveness against the severity of the disease. In the current study, low avidity antibodies of all the immunoglobulins predominated among subjects from the CM group, which could reflect the prevalence in this group of individuals with few previous malaria episodes. On the other hand, the predominance of low avidity antibodies could show that uncontrolled infection is related to an expression of immunodeficiency [50]. In general, IgG3 antibodies were low avidity, independently of the clinical expression of malaria. This could be explained by their short half-life ( 7-8 days) compared to the half-life of subclasses IgG1, IgG2 and IgG4 ( 23 days) [51,52] and it probably suggests that these antibodies are the main subclass of antibodies induced in response to new variants of polymorphic antigens of the erythrocytic stage of $P$. falciparum [53].

High overall levels of IgE have been found in populations exposed to malaria [17], a fact that was also observed in $94 \%$ of the individuals studied. However, there is some controversy as to the role of specific IgE antibodies and whether they serve to protect against the disease or to worsen the illness. The following findings could support the theory that specific IgE antibodies provide protection against malaria: a) positive correlations between IgE levels and age $[18,19]$; b) high concentration of IgE among individuals with severe non-comatose malaria in comparison to comatose individuals [54]; c) the association of high anti-P. falciparum IgE levels with a reduced risk of developing clinical malaria $[55,56]$.

On the other hand, other evidence suggests that IgE could play a role in the pathogenesis of malaria; for example: a) there is an increase of the levels of IgE among individuals suffering from severe malaria in comparison to uncomplicated malaria [17,57-59]; b) IgE deposits were found in brain microvessels and on parasited erythrocytes from cerebral malaria patients [19] and in placentas infected with $P$. falciparum [20]. Immunocomplexes of IgE with antigen or with IgG anti-IgE could induce the expression of Fce receptors in monocytes and the interaction with these receptors leads to the cellular activation and liberation of TNF $[60,61]$. Although TNF may protect against the parasites, local superproduction leads to tissue damage; in addition, elevated levels in the blood are related to sick- ness and death in cases of severe malaria $[62,63]$. Here, higher levels of IgE were observed among subjects suffered from complicated malaria, though the difference was not significantly higher $(P=0.07)$ for specific IgE found in the group of individuals with complicated malaria.

The frequencies of positivity and the levels of the IgM antibodies were higher among the primo-infected individuals than among those who claimed to have had previous bouts of malaria, decreasing with each additional previous episode. Primo-infected individuals were expected to have high IgM antibody levels, since IgM is the first class of antibody produced as a primary humoral response. This must also contribute to the predominance of IgM among subjects with complicated forms of malaria, since the majority of the primo-infected subjects were suffering from such forms of the disease.

The frequency of positivity of IgA antibodies does not have a correlation with the number of previous malaria episodes, though the IgA levels decreased with each previous episode. These results were in line with previous results when the predominance of IgA antibodies among primo-infected subjects was observed Since IgA deficiency has been observed among certain populations [64], total IgA levels were also investigated in this population, but these levels were normal.

\section{Conclusion}

The selection of the isotype and the antibody affinity maturation of an antibody are the results of a process of differentiating $B$ cells that occurs in the germinative centers of the lymph nodes of an immune individual. However, functional affinity or avidity depends on the antigen and on the selection of cell clones that produce antibodies with better cynetics for binding to the epitope. The selection of isotypes is a complex phenomenon that depends on several different mechanisms, many of which are still not fully understood [65]. The gradual development of protective immunity against malaria probably corresponds to a progressive modification in the regulation of the immune response and not to the slow development of a response or to poorly immunogenic or highly polymorphic molecules, as was believed for some time. Acquiring immunity would appear to be related to the ability to develop antibodies that, when bound to the antigen, are capable of activating cells by setting off defense mechanisms, reducing the proportion of antibodies with the same specificity and blocking cell activation [6]. Immunity to malaria results from a strong humoral immune response against multiple antigenic targets, as suggested by the inverse association of the risk of malaria with the breadth specificity for distinct merozoite antigens, AMA1, MSP-2, and MSP-3 [66], so it would be of interest to inves- 
tigate further the roles of different isotypes against multiple vaccine candidate antigens in different populations.

In conclusion, the work reported here suggests a differential regulation in the anti- $P$. falciparum antibody profile in different clinical expressions of malaria. Interactions of the antibodies IgG1, IgG2 and IgG3 were predominant among individuals from the AS and UM groups, while interactions between IgG4 and IgE prevailed among individuals from the $\mathrm{CM}$ group. The IgG2/IgG4 levels were higher in the AS and UM groups. The IgE/IgG levels were significantly higher among CM individuals than among those without clinical complications, which may suggest that the IgG and IgE antibodies reactive against the same epitopes could play exactly opposing functions during the infection. Therefore, the relationship between the antibodies IgG/IgE, IgG1-IgG2-IgG3/IgG4, IgG2/IgG4 and IgG4-IgE/IgG2 could reflect the balance between protection and pathogenesis in malaria.

These results show that even in populations from regions with unstable malaria transmission, a certain degree of naturally acquired immunity can develop when the right antibodies are produced. Also, the findings can contribute to a better understanding of the role of different isotypes in immunity to malaria and may provide new insights into the development of malaria control strategies, especially vaccination.

\section{Competing interests}

The authors declare that they have no competing interests.

\section{Authors' contributions}

FMSL made technical contributions to the entire work, including data interpretation of data and manuscript drafting. RRD, MVL and MGA contributed to patient selection and follow-up. AWF contributed to the conception of the study. MCAS assisted in the statistical analysis, interpretation of data and manuscript drafting. SLM participated in the conception, design, analysis and interpretation of data, and the final approval of the version to be published.

\section{Acknowledgements}

We would like to especially thank Dr. Cristóvão Luis Pitangueira Mangueira, Flávia Cristina Kinskowski and Milca Geane de Lamos Valim at the Central Laboratory of the Clinical Hospital for participating in the

determination of the total IgE and IgA levels. This work was supported by FAPESP (process number 200I/04073-5) and Laboratório de Investigações Médicas do Hospital das Clínicas da Faculdade de Medicina da Universidade de São Paulo (LIM-48/HCFMUSP)

\section{References}

I. Greenwood B: What can the residents of malaria endemic countries do to protect themselves against malaria? Parassitologia 1999, 41:295-299.
2. Bouharoun-Tayoun H, Oeuvray C, Lunel F, Druilhe P: Mechanisms underlying the monocyte-mediated antibody killing of Plasmodium falciparum asexual blood stages. J Exp Med 1995, I82:409-4|8.

3. Plebanski M, Hill AVS: The immunology of malaria. Curr Opin Immunol 2000, I 2:437-44I.

4. Bouharoun-Tayoun H, Attanath P, Sabchareon A, Chongsuphajaisiddhi T, Druilhe P: Antibodies that protect humans against Plasmodium falciparum blood stages do not on their own inhibit parasite growth and invasion in vitro, but act in cooperation with monocytes. J Exp Med 1990, I72:1633-I64I.

5. Groux H, Gysin J: Opsonization as an effector mechanism in human protection against asexual blood stages of Plasmodium falciparum: Functional role of IgG subclasses. Res Immunol 1990, I 41:529-542.

6. Bouharoun-Tayoun H, Druilhe P: Plasmodium falciparum malaria: Evidence for an isotype imbalance which may be responsible for delayed acquisition of protective immunity. Infect Immun 1992, 60:1473-I48I.

7. Garraud O, Mahanty S, Perraut R: Malaria-specific antibody subclasses in immune individuals: a key source of information for vaccine design. Trends Immunol 2003, 24:30-35.

8. Garraud O, Perraut R, Riveau G, Nutman : Class and subclass selection in parasite-specific antibody responses. Trends Parasitol 2003, I 9(7):300-304.

9. Aribot G, Rogier C, Sarthou JL, Trape JF, Balde AT, Druilhe P, Roussilhon C: Pattern of immunoglobulin isotype response to Plasmodium falciparum blood-stage antigens in individuals living in a holoendemic area of Senegal (Dielmo, West Africa). Am J Trop Med Hyg 1996, 54:449-457.

10. Shi YP, Sayed U, Qari SH, Robersts JM, Udhayakumar V, Oloo AJ, Hawley WA, Kaslow DC, Nahlen BL, Lal AA: Natural immune response to the C-terminal I9-kilodalton domain of Plasmodium falciparum merozoite surface protein I. Infect Immun 1996, 64:2716-2723.

II. Tangteerawatana P, Krudsood S, Chalermrut K, Looareesuwan S, Khusmith S: Natural human IgG subclass antibodies to Plasmodium falciparum blood stage antigens and their relation to malaria resistance in an endemic area of Thailand Southeast. South-East Asian J Trop Med Public Health 200I, 32:247-254.

12. Sarthou JL, Angel G, Aribot G, Rogier C, Dieye A, Balde AT, Diatta $B$, Seignot P, Roussilhon C: Prognostic value of anti-Plasmodium falciparum specific immunoglobulin $G 3$, cytokines, and their soluble receptors in West Africa patients with severe malaria. Infect Immun 1997, 65:327|-3276.

13. Warmerdam PA, Winkel JG Van de, Vlug A, Westerdaal NA, Capel PJ: A single amino acid in the second Ig-like domain of the human Fc $\gamma$ receptor II is critical for human IgG2 binding. J Immunol 1991, I47:I338-I343.

14. Aucan $C$, Traoré $Y$, Tall $F$, Nacro B, Traoré-Leroux $T$, Fumoux $F$, Rihet P: High immunoglobulin G2 (IgG2) and low G4 (IgG4) levels are associated with human resistance to Plasmodium falciparum malaria. Infect Immun 2000, 68: 1252-1258.

15. Troye-Blomberg M, Perlmann P, Nilsson M, Perlmann H: Immune regulation of protection and pathogenesis in Plasmodium falciparum malaria. Parassitologia 1999, 41:131-138.

16. Desowitz RS: Plasmodium falciparum immunoglobulin E in sera from an area of holoendemic malaria. Trans R Soc Trop Med Hyg 1989, 83:478-479.

17. Perlmann H, Helmby H, Hagstedt M, Carlson J, Larsson PH, TroyeBlomberg M, Perlmann P: IgE elevation and IgE anti-malarial antibodies in Plasmodium falciparum malaria: Association of high IgE levels with cerebral malaria. Clin Exp Immunol 1994, 97:284-292.

18. Desowitz RS, Elm J, Alpers MP: Plasmodium falciparum - Specific immunoglobulin $\mathbf{G}$ (IgG), IgM and IgE antibodies in paired maternal-cord sera from East Sepik Province, Papua New Guinea. Infect Immun 1993, 61 :988-993.

19. Maeno Y, Steketee R, Nagatake T, Tegoshi T, Desowitz RS, Wirima Jj, Aikawa M: Immunoglobulin complex deposits in Plasmodium falciparum-infected placentas from Malawi and Papua New Guinea. Am J Trop Med Hyg 1993, 49:574-580.

20. Maeno Y, Perlmann P, Perlmann H, Kusuhara Y, Taniguchi K, Nakabayashi T, Win K, Looarreesuwan S, Aikawa M: IgE Deposition in brain microvessels and on parasited erythrocytes from cerebral malaria patients. Am J Trop Med Hyg 2000, 63: I28-132. 
21. Luty AJF, Mayombo J, Lekoulou F, Mshana R: Immunologic Responses to Soluble Exoantigens of Plasmodium falciparum in Gabonese Children Exposed to Continuous Intense Infection. Am J Trop Med Hyg 1994, 5 I:720-729.

22. Duarte J, Deshpande P, Guiyedi V, Mécheri S, Fesel C, Cazenave P-A, Mishra GC, Kombila M, Pied S: Total and functional parasite specific IgE responses in Plasmodium falciparum-infected patients exhibiting different clinical status. Malar J 2007, 6:1-13.

23. Branch $\mathrm{OH}$, Udhayakumar $\mathrm{V}$, Hightower AW, Oloo AJ, Hawley WA, Nahlen BL, Bloland PB, Kaslow DC, Lal AA: A longitudinal investigation of IgG and IgM antibody response to the merozoite surface protein-I I9-kilodalton domain of Plasmodium falciparum in pregnant women and infants: associations with febrile illness parasitaemia and anemia. Am J Trop Med Hyg 1998, 58:211-219.

24. Jayawardena AN, Janeway CA, Kemp JD: Experimental malaria in the CBA/N mouse. J Immunol 1979, I 23:2532-2539.

25. Harte PG, Cooke A, Playfair JH: Specific monoclonal IgM is a potent adjuvant in murine malaria vaccination. Nature 1982, 302:256-258.

26. Boudin C, Chumptazi B, Dziegel M, Peyron F, Picot S, Hogh B, Ambroise-Thomas $P$ : Possible role of specific immunoglobulin $M$ antibodies to Plasmodium falciparum antigens in immunoprotection of human living in a hyperendemic area, Burkina Faso. J Clin Microbiol I993, 3 I:636-64I.

27. Avila SLM, Leandro MC, Carvalho NB, Oliveira MS, Arruk VG, Sanchez MCA, Boulos M, Ferreira AW: Evaluation of different methods for Plasmodia detection, in well defined population groups in an endemic area of Brazil. Rev Inst Med Trop Sao Paulo 1994, 36(2):157-162.

28. Plikaytis BD, Holder PF, Pais LB, Maslanka SE, Gheesling LL, Carlone GM: Determination of parallelism and nonparallelism in bioassay dilution curves. J Clin Microbiol I994, 32:244I-2447.

29. Jiang XM, Arepally G, Poncz M, Mckenzie S: Rapid detection of the Fc $\gamma$ RIIA-H/RI3I ligand- binding polymorphism using an allele- specific restriction enzyme digestion (ASRED). J Immunol Methods 1996, 199:55-59.

30. Snounou G, Viriyakosol S, Jarra W, Thaithong S, Brown KN: Identification of the four human malaria parasite species in field samples by the polymerase chain reaction and detection of a high prevalence of mixed infections. Mol Biochem Parasitol 1993, 58:283-292.

31. Ferreira MU, Liu Q, Zhou M, Kimura M, Kaneko O, Thien HV, Isomura S, Tanabe K, Kawamoto F: Stable patterns of allelic diversity at the merozoite surface protein-I locus of Plasmodium falciparum in clinical isolates from Southern Vietnam. J Eukaryot Microbiol 1998, 45:|3|-136.

32. Dubois B, Deleron P, Astagneau P, Chougnet C, Lepers JP: Isotypic analysis of Plasmodium falciparum-specific antibodies and their relation to protection in Madagascar. Infect Immun 1993, 6I:4498-4500.

33. Rzepczyk CM, Hale K, Woodroffe N, Bobogare A, Csurhers P, Ishii $A$, Ferrante A: Humoral immune responses of Solomon Islanders to the merozoite surface antigen 2 of Plasmodium falciparum show pronounced skewing towards antibodies of the immunoglobulin G3 subclass. Infect Immun 1997, 65: I098-I I 00.

34. Taylor RR, Allen SJ, Grenwood BM, Riley EM: IgG3 antibodies to Plasmodium falciparum merozoite surface protein 2 (MSP2): increasing prevalence with age and association with clinical immunity to malaria. Am J Trop Med Hyg 1998, 58:406-4I3.

35. Tangteerawatana P, Montgomery SM, Perlmann H, Looareesuwan S, Troye-Blomberg M, Khusmith S: Differential regulation of IgG subclasses and IgE antimalarial antibody responses in complicated and uncomplicated Plasmodium falciparum malaria. Parasite Immunol 2007, 29:475-483.

36. Lucchi NW, Tongren JE, Jain V, Nagpal AC, Kauth CW, Woehlbier U, Bujard H, Dash AP, Singh N, Stiles JK, Udhayakumar V: Antibody responses to the merozoite surface protein-I complex in cerebral malaria patients in India. Malar / 2008, 7:121-134.

37. A-Elgadir TME, Elbashir MI, Berzins K, Masuadi EM, A-Elbasit IE, EIGhazali $\mathrm{G}$, Giha $\mathrm{HA}$ : The profile of IgG-antibody response against merozoite surface proteins $I$ and $\mathbf{2}$ in severe Plasmodium falciparum malaria in Eastern Sudan. Parasitol Res 2008, 102:401-409.
38. Nebie I, Diarra A, Ouedraogo A, Soulama I, Bougouma EC, Tiono AB, Konate AT, Chilengi R, Theisen M, Dodoo D, Remarque E, Bosomprah S, Milligan P, Sirima SB: Humoral responses to Plasmodium falciparum blood-stage antigens and association with incidence of clinical malaria in children living in an area of seasonal malaria transmission in Burkina Faso, West Africa. Infect Immun 2008, 76:759-766.

39. de Andrade AL, Martelli CM, Oliveira RM, Arias JR, Zicker F, Pang L: High prevalence of asymptomatic malaria in gold mining areas in Brazil. Clin Infect Dis 1995, 20:475.

40. Alves FP, Durlacher RR, Menezes MJ, Krieger H, da Silva LHP, Camargo EP: High prevalence of asymptomatic Plasmodium vivax and Plasmodium falciparum infections in native Amazonian populations. Am J Trop Med Hyg 2002, 66:64I-648.

4I. Tebo AE, Kremsner PG, Luty AJ: Fc gamma receptor-mediated phagocytosis of Plasmodium falciparum-infected erythrocytes in vitro. Clin Exp Immunol 2002, I30:300-306.

42. Omi K, Ohashi J, Patarapotikul J, Hananantachai H, Naka I, Looareesuwan S, Tokunaga K: Fc gamma receptor IIA and IIIB polymorphisms are associated with susceptibility to cerebral malaria. Parasitol Int 2002, 5 I:361-366.

43. Cooke GS, Aucan C, Walley AJ, Segal S, Greenwood BM, Kwiatkowski DC, Hill AVS: Association of $F c \gamma$ receptor IIA (CD32) polymorphism with severe malaria in West Africa. Am J Trop Med Hyg 2003, 69:565-568.

44. Nasr A, Iriemenam NC, Troye-Blomberg M, Giha HA, Balogun HA, Osman OF, Montgomery SM, ElGhazali G, Berzins K: Fc gamma receptor Ila (CD32) polymorphism and antibody responses to asexual blood-stage antigens of Plasmodium falciparum malaria in Sudanese patients. Scand J Immunol 2007, 66:87-96.

45. Ouma C, Keller CC, Opondo DA, Were T, Otieno RO, Otieno MF, Orago ASS, Ong'echa JM, Vulule JM, Ferrell RE, Perkins DJ: Association of $\mathrm{Fc} \gamma$ receptor IIA (CD32) polymorphism with malarial anemia and high-density parasitemia in infants and young children. Am J Trop Med Hyg 2006, 74:573-577.

46. Shi YP, Nahlen BL, Kariuki S, Urdahl KB, McElroy PD, Roberts JM, Lal AA: Fc $\gamma$ receptor Ila (CD32) polymorphism is associated with protection of infants against high-density Plasmodium falciparum Infection. VII. Asembo Bay Cohort Project. J Infect Dis 200I, 184:107-III.

47. Yee AMF, Phan HM, Zuniga R, Salmon JE, Musher DM: Association between FcgRIla-R I 3 I allotype and bacteremic pneumococcal pneumonia. Clin Infect Dis 2000, 30:25-28.

48. Bredius RG, de Vries CE, Troelstra A, van Alphen L, Weening RS, Winkel JG van de, Out TA: Phagocytosis of Staphylococcus aureus and Haemophilus influenzae type B opsonized with polyclonal human IgGI and IgG2 antibodies. Functional hFc gamma RIla polymorphism to IgG2. I Immunol 1993, 151: | 1463-1472

49. Sanders LA, Winkel JG van de, Rijkers GT, Voorhorst-Ogink MM, de Haas M, Capel PJ, Zegers BJ: Fc gamma receptor Ila (CD32) heterogeneity in patients with recurrent bacterial respiratory tract infections. J Infect Dis 1994, 170:854-86I.

50. Ferreira MU, Kimura EAS, Souza JM, Katzin AM: The isotype composition and avidity of naturally acquired anti-Plasmodium falciparum a ntibodies: differential patterns in clinically immune Africans and Amazonians patients. Am J Trop Med Hyg 1996, 55:315-323.

5I. Abbas AK, Lichtman AH, Pillai S: Cellular and Molecular Immunology 6th edition. Philadelphia: Saunders Elsevier; 2007.

52. Winkler S, Willheim M, Baier K, Schmid D, Aichelburg A, Graninger W, Kremsner PG: Reciprocal regulation of Th1- and Th2cytokine-producing $T$ cells during clearance of parasitemia in Plasmodium falciparum malaria. Infect Immun 1998, 66:6040-6044.

53. Garraud O, Perraut R, Diouf A, Nambei WS, Tall A, Spiegel A, Longacre S, Kaslow DC, Jouin H, Mattei D, Engler GM, Nutman TB, Riley EM, Mercereau-Puijalon O: Regulation of antigen-specific immunoglobulin $\mathbf{G}$ subclasses in response to conserved and polymorphic Plasmodium falciparum antigens in an in vitro model. Infect Immun 2002, 70:2820-2827.

54. Calissano C, Modiano D, Sirima BS, Konate A, Sanou I, Sawadogo A, Perlmann H, Troye-Blomberg M, Perlmann P: IgE antibodies to Plasmodium falciparum and severity of malaria in children of one ethnic group living in Burkina Faso. Am J Trop Med Hyg 2003, 69:31-35. 
55. Bereczky S, Montgomery SM, Troye-Blomberg M, Rooth I, Shaw MA, Farnert $A$ : Elevated anti-malarial IgE in asymptomatic individuals is associated with reduced risk for subsequent clinical malaria. Int J Parasitol 2004, 34:935-942.

56. Farouk SE, Dolo A, Bereczky S, Kouriba B, Maiga B, Farnert A, Perlmann H, Hayano M, Montgomery SM, Doumbo OK, Troye-Blomberg M: Different antibody- and cytokine-mediated responses to $P$. falciparum parasite in two sympatric ethnic tribes living in Mali. Microbes Infect 2005, 7: I I0-1 I7.

57. Perlmann P, Perlmann H, Flyg BW, Hagstedt M, Elghazali G, Worku S, Fernandez V, Rutta AS, Troye-Blomberg M: Immunoglobulin E, a pathogenic factor in P. falciparum malaria. Infect Immun 1997, 65:|16-|2|.

58. Perlmann P, PerImann H, Looareesuwan S, Krudsood S, Kano S, Matsumoto Y, Brittenham G, Troye-Blomberg M, Aikawa M: Contrasting functions of IgG and IgE antimalarial antibodies in uncomplicated and severe $\boldsymbol{P}$. falciparum malaria. Am J Trop Med Hyg 2000, 62:373-377.

59. Seka-Seka J, Brouh Y, Yapo-Crezoit AC, Atseye NH: The role of serum immunoglobulin $E$ in the pathogenesis of $P$. falciparum malaria in Ivorian children. Scand J Immunol 2004, 59:228-230.

60. Elghazali G, Perlmann H, Rutta AS, Perlmann P, Troye-Blomberg M: Elevated plasma levels of IgE in Plasmodium falciparumprimed individuals reflect an increased ratio of IL-4 to interferon-gamma (IFN-gamma)-producing cells. Clin Exp Immunol 1997, 109:84-89.

61. Perlmann P, Perlmann H, EIGhazali G, Blomberg MT: IgE and tumor necrosis factor in malaria infection. Immunol Lett 1999, 65:29-33.

62. Grau GE, Piguet P-F, Vassali P, Lambert P-H: Tumor-necrosis factor and disease severity in children with Plasmodium falciparum. N Engl J Med 1989, 320:1586-1591.

63. Kwiatkowski D, Hill AV, Sambou I, Twumasi P, Castracane J, Manogue KR, Cerami A, Brewster DR, Greenwood BM: TNF concentration in fatal cerebral, non-fatal cerebral, and uncomplicated Plasmodium falciparum malaria. Lancet 1990, 336: I20I-I 204.

64. Thakar YS, Chande C, Dhanvijay AG, Pande S, Saoji AM: Analysis of immunoglobulin deficiency cases: a five year study. Indian J Pathol Microbiol 1997, 40:309-13.

65. Manis JP, Tian M, Alt FW: Mechanism and control of class-switch recombination. Trends Immunol 2002, 23:3I-39.

66. Osier FHA, Fegan G, Polley SD, Murungi L, Verra F, Tetteh KKA, Lowe B, Mwangi T, Bull PC, Thomas AW, Cavanagh DR, McBride JS, Lanar DE, Mackinnon MJ, Conway DJ, Marsh K: Breadth and magnitude of antibody responses to multiple Plasmodium falciparum merozoite antigens are associated with protection from clinical malaria. Infect Immun 2008, 76:2240-2248.

Publish with Biomed Central and every scientist can read your work free of charge

"BioMed Central will be the most significant development for disseminating the results of biomedical research in our lifetime. "

Sir Paul Nurse, Cancer Research UK

Your research papers will be:

- available free of charge to the entire biomedical community

- peer reviewed and published immediately upon acceptance

- cited in PubMed and archived on PubMed Central

- yours - you keep the copyright

Submit your manuscript here:

http://www.biomedcentral.com/info/publishing_adv.asp
BioMedcentral 